\title{
Overview of the Oral Hygiene Status of Students in SDN Pucang 3 Sidoarjo Based on Their Toothbrushing Habit by Titiek Berniyanti
}

Submission date: 18-Mar-2019 10:01AM (UTC+0800)

Submission ID: 1094974412

File name: in_SDN_Pucang_3_Sidoarjo_based_on_their_toothbrushing_habit.pdf (230.19K) Word count: 5474 


\title{
Overview of the Oral Hygiene Status of Students in SDN Pucang 3 Sidoarjo Based on Their Toothbrushing Habit
}

\author{
Titiek Berniyanti, Irjinia Putri Nanda A., Roesanto Heroesoebekti, Retno Palupi, Agung Sosiawan, \\ 4 Taufan Bramantoro, Gilang Rasuna Sabdho Wening and R.Darmawan Setijanto \\ Department of Dental Public Health, Faculty of Dentistry, Airlangga University, Surabaya - Indonesia \\ berniyanti@gmail.com
}

Keywords: Oral Hygiene Status, Toothbrushing Habit, PHPI, SDN Pucang 3 Sidoarjo

Abstract: $\quad$ The level of oral hygiene can be measured by the presence of plaque in the oral cavity. One of the easiest ways to maintain oral hygiene status is by toothbrushing. But there are many Indonesian people who are still not aware of the importance of toothbrushing before bedtime, so the risk of oral disease can increase. Especially infants are more susceptible to oral disease. To describe the oral hygiene status of students in SDN Pucang 3 Sidoarjo, based on their toothbrushing habit. This research was a descriptive observational study with a cross-sectional approach. The research instrument to collect data of oral hygiene status was the PHP Index. Collection of data of other variables was achieved by interviewing the subjects, video observation of how they brush their teeth, toothbrushing observation of subjects, and a questionnaire to parents about the brushing habits of the subjects. The mean oral hygiene status of subjects was 1.375 . The results of this study found a significant association between oral hygiene status of subjects with teeth brush surface of the subjects. In a certain group, there was a relationship between toothbrushing habits of subjects and the economics of the parents, education of parents, access to oral health services of subjects, and education of subjects about oral hygiene status. The results of oral hygiene status of students in SDN Pucang 3 Sidoarjo was in the good category with a mean of 1.375 . There is a relation to oral hygiene.

\section{INTRODUCTION}

Dental and oral hygiene is part of the body's hygiene as a whole, because the oral cavity is one of the entry ports of the general health status alteration factors (Gopikrishna et al., 2016). A person's level of dental and oral hygiene can be measured by assessing the presence of plaque and calculus on the tooth surface (Soesilo et al., 2005). Mantaining dental and oral hygiene is an important thing because it is done without any supervision from anybody, and is influenced by knowledge of maintaining one's oral hygiene. One of the easiest and familiar ways to do it is by brushing the teeth and oral cavity regularly (Maruanaya, Mariati \& Pangemanan, 2015)

Based on the RISKESDAS data in 2013, Indonesians who do daily toothbrushing routinely is $93.8 \%$. Even though the habit of brushing teeth is known and made to be a routine by society, according to RISKESDAS data of 2013, the national prevalence of dental and oral problems is still high at $25.9 \%$, and there are 14 provinces that still have a prevalence of dental and oral problems higher than the national average, including East Java. This might be because society does not understand how to brush teeth in the right and correct way. Supported by the RISKESDAS data of 2013 that showed that Indonesian society has the habit of toothbrushing in morning and evening baths, only $27.3 \%$ of them brush their teeth before sleeping at night (Trihono, 2013). This shows that there are still many Indonesians who have not yet realized the importance of brushing teeth optimally, thus causing the teeth to be at risk of dental and oral diseases. In accordance with the opinion above, the habit of brushing teeth and the oral cavity is considered a form of behavior that will influence whether the dental and oral hygiene is good or bad.

Knowledge regarding dental and oral hygiene is best started in adolescence because children in this range of age start to understand the importance of health and the habits that could influence their teeth's condition. Primary school age is the ideal age to practice the motoric skills of a child, including the habit of brushing the teeth. Children at this age

204

Berniyanti, T., A., I., Heroesoebekti, R., Palupi, R., Sosiawan, A., Bramantoro, T., Wening, G. and Setijanto, R.

Overview of the Oral Hygiene Status of Students in SDN Pucang 3 Sidoarjo Based on Their Toothbrushing Habit.

In Proceedings of The 7th international Meeting and The 4th Joint Scientific Meeting in Dentistry (TIMNAS7-JSMID4) (TIMNAS7.JSMID4 2017), pages 204-211

ISBN: $978-989-758-341.4$

Copyright $@ 2018$ by SCITEPRESS - Science and Technology Publications, Lda. All rights reserved 
belong to the group susceptible to dental and oral diseases (Sabrina et al., 2015).

Observations of the habit of brushing teeth in primary school children actually still could be optimized. This is based on the opinion that an action is more valid to be observed through the action of toothbrushing itself, not through interviews. Realizing this, this study tried to reveal the habit of primary school children's toothbrushing habit through the observation of toothbrushing itself. The observation method that was done was using video recordings of the subject's toothbrushing activity, whereas a few variables impossible to be observed in the recording were asked about directly through interviews of the subject as well as the parents of the subject. Obviously, there are other risk factors internally and externally from primary school students that also play a role in their dental and oral hygiene status. Because of this, this study also studied various factors regarding the interaction between the habit of brushing the teeth with the dental and oral hygiene status.

Sidoarjo is classified as a developing city. The public health office system in Sidoarjo is pretty good, seen from the frequent counselings about how to maintain dental and oral hygiene and also school health (UKS; Usaha Kesehatan Sekolah) that is directed well and classified as good in East Java, but the Public Health Office in Sidoarjo does not have written data about the annual dental and oral hygiene status. SDN Pucang 3 Sidoarjo is one of the primary schools that is located in the city center of Sidoarjo. SDN Pucang 3 Sidoarjo is included as the school that has already received counseling about dental and oral hygiene by the Public Health Officials; theoretically those various counseling could result in improvement of the dental and oral hygiene quality, but there has not been any written data about the dental and oral hygiene status in the students of SDN Pucang 3 Sidoarjo (Notoatmodjo, 2010).

Based on the background above, the writer wished to do a study about the dental and oral hygiene status of the students of SDN Pucang 3 Sidoarjo based on the habit of brushing teeth. It is hoped that the result of this study could become data to understand the relation between the habit of toothbrushing and their oral hygiene status.

\section{MATERIALS AND METHODS}

This research was an observational descriptive study with a cross-sectional approach that aimed to ascertain the description of dental and oral hygiene status of students of SDN Pucang 3 Sidoarjo. The number of samples was 100 people selected by stratified random sampling. The sample composition of this study consisted of 50 male subjects and 50 female subjects, from grade 1 to grade 5, ranging in age from 6 to 12 years. Grade 6 students were not included as the subject of research due to being focused on exam preparation.

Initially, the oral cavities of the research subjects were disclosed with a disclosing agent and the hygiene status of the oral cavity was assessed using the PHPI (Personal Hygiene Performance Index) measuring tool as well as the examination of its gel composition, then the subjects were interviewed about their habit of brushing their teeth, and knowledge about oral hygiene, and dental and oral health services. Then the subjects performed activities with a toothbrush while being recorded and an inspection of the toothbrush commonly used by the subject. Subsequently, a questionnaire was given to the parents of the subjects who were entrusted through the subjects. The data obtained was processed, dental and oral hygiene status was crosstabulated using SPSS 17 application against several risk factors, and divided into certain groups.

\section{RESULTS}

In this study the status of oral hygiene was assessed using the PHPI (Personal Hygiene Performance Index). In the subjects a range of PHPI score was obtained being $0-4.6$ with the average population being 1.375 and with a standard deviation of 0.73 . Oral and oral hygiene status was divided into 2 categories: score $>1.375$ indicating poor dental and oral hygiene status, and $\leq 1.375$ indicating good dental and oral hygiene status.

Based on Figure 1 the score of the PHPI showed that as much as $56 \%$ of the research subjects had a poor dental and oral hygiene status, and $44 \%$ of the subjects had a good dental and oral hygiene status. 


\section{the status of oral hygiene}

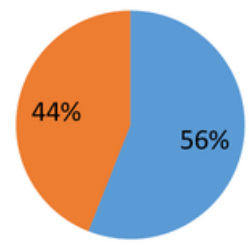

घ $>1,375 \square \leq 1,375$

Figure 1: Distribution of oral hygiene status of students of SDN Pucang 3 Sidoarjo.

The dental and oral hygiene status of students of SDN Pucang 3 Sidoarjo could be influenced by intrinsic and extrinsic factors. The intrinsic factors are gender, age, and the subject's teeth alignment. Extrinsic factors are factors that can be derived from the subject's understanding and habits to maintain oral health, including the habit of brushing teeth, the subjects' habit of accessing dental and oral health services, as well as the subject's knowledge of oral hygiene status (how to maintain oral hygiene and clinical symptoms).

Table 1: The dental and oral hygiene status of Pucang 3 Sidoarjo students based on intrinsic factors.

\begin{tabular}{|c|c|c|c|c|}
\hline & & \multicolumn{2}{|c|}{$\begin{array}{c}\text { Oral hygiene } \\
\text { status }\end{array}$} & \multirow[t]{2}{*}{ Total } \\
\hline & & $>1.375$ & $\leq 1.375$ & \\
\hline \multirow{2}{*}{ Gender } & Male & $\begin{array}{c}31 \\
(62 \%)\end{array}$ & $\begin{array}{c}19 \\
(38 \%)\end{array}$ & 50 \\
\hline & Female & $\begin{array}{c}25 \\
(50 \%)\end{array}$ & $\begin{array}{c}25 \\
(50 \%)\end{array}$ & 50 \\
\hline \multirow{2}{*}{ Age } & $6-8$ yo & $\begin{array}{c}21 \\
(50 \%)\end{array}$ & $\begin{array}{c}21 \\
(50 \%)\end{array}$ & 42 \\
\hline & $9-12$ yo & $\begin{array}{c}35 \\
(60.3 \%) \\
\end{array}$ & $\begin{array}{c}23 \\
(39.7 \%) \\
\end{array}$ & 58 \\
\hline \multirow{2}{*}{$\begin{array}{c}\text { The } \\
\text { subject's } \\
\text { teeth } \\
\text { alignment }\end{array}$} & Crowding & $\begin{array}{c}13 \\
(61.9 \%)\end{array}$ & $\begin{array}{c}8 \\
(38.1 \%)\end{array}$ & 21 \\
\hline & Normal & $\begin{array}{c}43 \\
(54.4 \%)\end{array}$ & $\begin{array}{c}36 \\
(45.6 \%)\end{array}$ & 79 \\
\hline
\end{tabular}

Based on the result of cross tabulation in table 1 , the dental and oral hygiene status of Pucang 3 Sidoarjo students based on intrinsic factor showed that the subjects who were male in gender had a worse dental and oral hygiene status compared to the females. Subjects in the 9-12 years age group had dental and oral hygiene status worse than the subjects in the age group of $6-8$ years. Subjects with crowded teeth had a worse dental and oral hygiene status than normal.

Table 2: The dental and oral hygiene status of Pucang 3 Sidoarjo students based on the subjects' brushing habits.

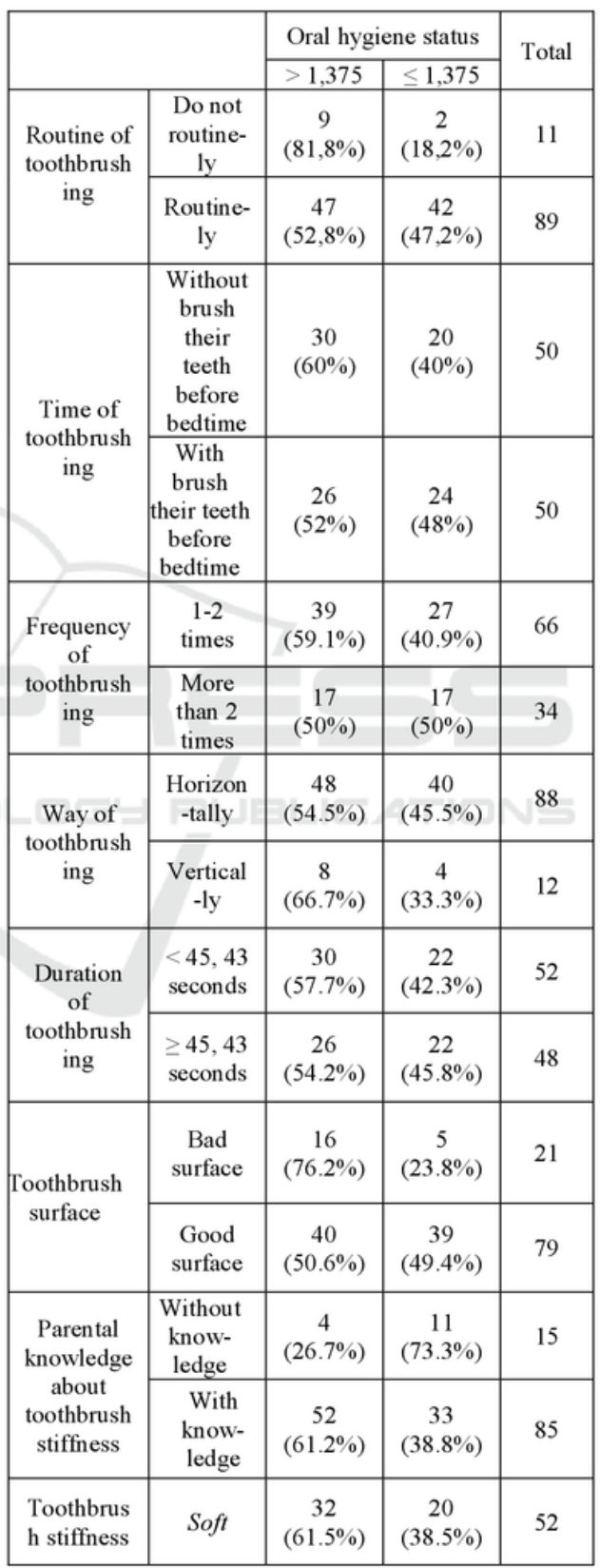




\begin{tabular}{|c|c|c|c|c|}
\hline & $\begin{array}{l}\text { Medium } \\
\text {-hard }\end{array}$ & $\begin{array}{c}19 \\
(57.6 \%)\end{array}$ & $\begin{array}{c}14 \\
(42.4 \%)\end{array}$ & 33 \\
\hline \multirow{2}{*}{$\begin{array}{c}\text { Tooth- } \\
\text { brush } \\
\text { replace- } \\
\text { ment } \\
\text { periods }\end{array}$} & $\begin{array}{c}\text { Without } \\
\text { tooth- } \\
\text { brush } \\
\text { replace- } \\
\text { ment } \\
\text { periods }\end{array}$ & $\begin{array}{c}25 \\
(65.8 \%)\end{array}$ & $\begin{array}{c}13 \\
(34.2 \%)\end{array}$ & 38 \\
\hline & $\begin{array}{l}\text { With } \\
\text { tooth- } \\
\text { brush } \\
\text { replace- } \\
\text { ment } \\
\text { periods }\end{array}$ & $\begin{array}{c}31 \\
(50 \%)\end{array}$ & $\begin{array}{c}31 \\
(50 \%)\end{array}$ & 62 \\
\hline \multirow{2}{*}{$\begin{array}{l}\text { Tooth- } \\
\text { brush } \\
\text { replace- } \\
\text { ment } \\
\text { periods }\end{array}$} & $\begin{array}{c}>3 \\
\text { month }\end{array}$ & $\begin{array}{c}7 \\
(63.6 \%)\end{array}$ & $\begin{array}{c}4 \\
(36.4 \%)\end{array}$ & 11 \\
\hline & $\begin{array}{c}1-3 \\
\text { month }\end{array}$ & $\begin{array}{c}24 \\
(47.1 \%)\end{array}$ & $\begin{array}{c}27 \\
(52.9 \%)\end{array}$ & 51 \\
\hline
\end{tabular}

The subjects' brushing habits including routine, time, frequency, way, duration, toothbrush surface, parental knowledge about toothbrush stiffness, and toothbrush replacement periods.

Based on the results of cross-tabulation in Table 2 it was found that subjects who do not routinely brush their teeth have poor dental and oral hygiene status. Subject groups who did not brush their teeth before bedtime had a poor dental and oral hygiene status. Subject groups that had a toothbrushing frequency of 1-2 times a day had poor dental and oral hygiene status. In the group of subjects who brushed their teeth vertically they also had poor dental and oral hygiene status. Subject groups that brushed teeth with a shorter duration had poor dental and oral hygiene status. In the group of subjects who had a toothbrush with bristles damaged they had poor dental and oral hygiene status. In the parental group, subjects with knowledge of oral hygiene status had poor dental and oral hygiene status. In groups of subjects who did not have toothbrush replacement periods they had poor dental and oral hygiene status, and those having a replacement period of more than 3 months also had poor dental and oral hygiene status.

Dental and oral hygiene status with the habit of toothbrushing may be related to particular groups such as the parents' background (incomes and education), subjects' behaviors of accessing dental and oral health services, and the subject's knowledge of how to maintain oral hygiene.

Table 3: The dental and oral hygiene status of Pucang 3 Sidoarjo students based on the group of subjects.

\begin{tabular}{|c|c|c|c|c|}
\hline \multirow{2}{*}{} & \multicolumn{3}{|c|}{ Oral hygiene status } & \multirow{2}{*}{ Total } \\
\cline { 2 - 5 } & $>1,375$ & $\leq 1,375$ & \\
\hline Group of parents with education under senior high \\
school
\end{tabular}




\begin{tabular}{|c|c|c|c|c|}
\hline $\begin{array}{c}\text { toothbrus } \\
\text { hing }\end{array}$ & $\begin{array}{c}\text { second } \\
\mathrm{s}\end{array}$ & & & \\
\cline { 2 - 5 } & $\geq 45$, & & & \\
& $\begin{array}{c}43 \\
\text { second } \\
\mathrm{s}\end{array}$ & $\begin{array}{c}5 \\
(41.7 \%)\end{array}$ & $7(58.3 \%)$ & 12 \\
\hline
\end{tabular}

Group of parents with earning a high income

\begin{tabular}{|c|c|c|c|c|}
\hline \multirow{2}{*}{$\begin{array}{l}\text { Duration } \\
\text { of } \\
\text { toothbrus } \\
\text { hing }\end{array}$} & $\begin{array}{l}<45,43 \\
\text { second }\end{array}$ & $\begin{array}{c}19 \\
(59,4 \%)\end{array}$ & $\begin{array}{c}13 \\
(40,6 \%)\end{array}$ & 32 \\
\hline & $\begin{array}{l}\geq 45,43 \\
\text { second }\end{array}$ & $\begin{array}{c}11 \\
(44 \%)\end{array}$ & $14(56 \%)$ & 25 \\
\hline \multicolumn{5}{|c|}{$\begin{array}{c}\text { Group of subjects who have accessed dental and oral } \\
\text { health services }\end{array}$} \\
\hline \multirow{2}{*}{$\begin{array}{l}\text { Duration } \\
\text { of } \\
\text { toothbrus } \\
\text { hing }\end{array}$} & $\begin{array}{l}<45,43 \\
\text { second }\end{array}$ & $\begin{array}{c}17 \\
(73,9 \%)\end{array}$ & $6(26,1 \%)$ & 23 \\
\hline & $\begin{array}{l}\geq 45,43 \\
\text { second }\end{array}$ & $\begin{array}{c}9 \\
(47,4 \%)\end{array}$ & $\begin{array}{c}10 \\
(52,6 \%)\end{array}$ & 19 \\
\hline
\end{tabular}

Group of parents with education under senior high school

\begin{tabular}{|c|c|c|c|c|}
\hline \multirow{2}{*}{$\begin{array}{c}\text { Toothbrush } \\
\text { surface }\end{array}$} & $\begin{array}{c}\text { Bad } \\
\text { surface }\end{array}$ & $6(75 \%)$ & $2(25 \%)$ & 8 \\
\cline { 2 - 5 } & $\begin{array}{c}\text { Good } \\
\text { surface }\end{array}$ & $\begin{array}{c}11 \\
(45,8 \%)\end{array}$ & $\begin{array}{c}13 \\
(54,2 \%)\end{array}$ & 24 \\
\hline
\end{tabular}

Group of parents had high income

\begin{tabular}{|c|c|c|c|c|}
\hline \multirow{2}{*}{$\begin{array}{l}\text { Toothbrush } \\
\text { surface }\end{array}$} & $\begin{array}{c}\text { Bad } \\
\text { surface }\end{array}$ & $\begin{array}{c}8 \\
(66.7 \%)\end{array}$ & $4(33.3 \%)$ & 12 \\
\hline & $\begin{array}{l}\text { Good } \\
\text { surface }\end{array}$ & $\begin{array}{c}22 \\
(48.9 \%)\end{array}$ & $\begin{array}{c}23 \\
(51.1 \%)\end{array}$ & 45 \\
\hline
\end{tabular}

Group of subjects with no knowledge of how to maintain oral hygiene

\begin{tabular}{|c|c|c|c|c|}
\hline & $\begin{array}{c}\text { Bad } \\
\text { surface }\end{array}$ & $\begin{array}{c}2 \\
(100 \%)\end{array}$ & $0(0 \%)$ & 2 \\
\cline { 2 - 5 } $\begin{array}{c}\text { Toothbrush } \\
\text { surface }\end{array}$ & $\begin{array}{c}\text { Good } \\
\text { surface }\end{array}$ & $\begin{array}{c}3 \\
(42.9 \%)\end{array}$ & $4(57.1 \%)$ & 7 \\
\hline
\end{tabular}

Group of parents who have never accessed dental and oral health services

\begin{tabular}{|c|c|c|c|c|}
\hline \multirow{2}{*}{$\begin{array}{c}\text { Toothbrush } \\
\text { surface }\end{array}$} & $\begin{array}{c}\text { Bad } \\
\text { surface }\end{array}$ & $\begin{array}{c}12 \\
(75 \%)\end{array}$ & $4(25 \%)$ & 16 \\
\cline { 2 - 5 } & $\begin{array}{c}\text { Good } \\
\text { surface }\end{array}$ & $\begin{array}{c}18 \\
(42.9 \%)\end{array}$ & $\begin{array}{c}24 \\
(57.1 \%)\end{array}$ & 42 \\
\hline
\end{tabular}

Dental and oral hygiene status with the habit of toothbrushing may be related to particular groups such as the parents' background (incomes and education), subjects' behaviors of accessing dental and oral health services, and the subject's knowledge of how to maintain oral hygiene.

Based on the cross-tabulation in Table 3, the group of subjects who routinely brushed their teeth had good dental and oral hygiene status while the non-routine group had poor dental and oral hygiene status in the background group of parents with education under senior high school, had a high income, and never accessed dental and oral health services. At the time of toothbrushing, good oral hygiene status is achieved when subjects brush their teeth at nighttime and the dental and oral hygiene status was bad if the subjects brushed their teeth without brushing at night and were included in the group of subjects who have parents with educational background above Senior High School. Based on how to brush teeth of the subject, the group of subjects who brushed their teeth with vertical movements had poor dental and oral hygiene status. This condition occurred in the groups of subjects who had never accessed dental and oral health services. Based on the duration of brushing, the group who brushed their teeth for a short duration had poor dental and oral hygiene status. This condition occurred in the subject group of parent education under senior high school, earning a high income, and the group of subjects who had accessed dental and oral health services. Based on the shape of the toothbrush, the shape of a broken toothbrush showed poor dental and oral hygiene status. This condition occurred in the parent education group below senior high school, earning a high income, and the subjects with no knowledge of how to maintain oral hygiene never accessed dental and oral services.

\section{DISCUSSION}

The dental and oral hygiene status of a person may change over a period of time, as this is influenced by several risk factors associated such things as dietary habits, supported by the study of differences in oral hygiene status upon arrival and departing school by Viviana S. (2015). The data obtained in the study at SDN Pucang 3 Sidoarjo, used the assessment of PHP-I scores of the subjects with an average of 1.375 with a 0.73 standard deviation.

The male subjects group had worse dental and oral hygiene status than the female subject group. This result is in accordance with the theory by 
Azodo that women are better at maintaining their oral and mouth hygiene than men (Oberoi et al., 2014).

Another intrinsic factor is the age of the study subjects, the 9-12 year age group having a worse dental and oral hygiene status than the 6-8 year age group. This is inconsistent with the theory that as children age, a child will have better knowledge in maintaining oral hygiene

If the dental and oral hygiene status is outlined according to the teeth alignment, a crowded alignment has worse dental and oral hygiene status than subjects with normal dental alignment. This is because teeth that are crammed tend to be more difficult to clean when brushing them because when brushing teeth, it will be hard for the toothbrush to reach the rest of the food stuck in the interdental area, so this condition can cause the buildup of dental plaque (Sasea et al., 2013).

The habit of toothbrushing is one of the major risk factors that plays a role in eliminating plaque, which is included in the risk factors affecting dental and oral hygiene status. In the non-toothbrushing subjects, they had poor dental and oral hygiene status compared to the subjects who routinely brushed their teeth. This is in accordance with the theory expressed by Angela (2005) that maintaining oral hygiene that is supported with routine brushing of teeth can eliminate more plaque (Oberoi et al. 2014). The result of cross-tabulation of toothbrushing routine with dental and oral hygiene status is an odds ratio of 4.021 .

In certain groups, subjects who regularly brush their teeth have good dental and oral hygiene status while the non-routine group has poor dental and oral hygiene status. Based on the result of crosstabulation of related routines on dental and oral hygiene status, there was a group of subjects with parents' education background under senior high school, earning a high income, and never having accessed dental and oral health services.

If oral and oral hygiene status is associated with the time of toothbrushing, the group of subjects who do not brush their teeth before bedtime had a worse dental and oral hygiene status than the group of subjects who brushed their teeth before bedtime. This is in accordance with Bracika's theory (2014) which states that the most important time to brush one's teeth is before bed, because during sleep the production of saliva decreases, so that the saliva flow is reduced which causes the decreased effect of self-cleansing; thus, plaque will be maturated (Bracika, 2014). Cross-tabulation results of brushing with dental and oral hygiene status has an odds ratio of 1.385 .

Based on cross-tabulation results obtained of brushing teeth related to dental and oral hygiene status in groups of subjects who have parents with educational background above senior high school, the status of dental hygiene and the mouth is good if subjects brush their teeth at night and the dental and oral hygiene is bad if subjects do not brush their teeth at night.

In the group of subjects who brushed 1-2 times a day they had poor dental and oral hygiene status compared to the group who brushed their teeth more than 2 times a day. Based on the theory according to the American Dental Association (ADA) it is stated that toothbrushing should be twice a day, as a low frequency of toothbrushing can cause more plaque accumulation (Hayasaki et al., 2014). However, according to previous research by Nizal (2013), the timeliness / time to brush teeth is more important than increasing the frequency of toothbrushing to improve the dental and oral hygiene status thus the brushing frequency is not cross-tabulated in a particular group.

Subject groups who brush their teeth vertically have poorer dental and oral hygiene status than those who brush their teeth in a horizontal way. Based on the theory stated by Sihite (2011), a simple toothbrushing method is more effective for children to keep their teeth and mouth clean, because the effectiveness of brushing teeth can reduce the potential of the remaining food to stick to plaque (Sabrina et al., 2015). Based on the cross-tabulation result, brushing method has an odds ratio of 1.667 .

Based on the result of cross-tabulation it was found that the way of toothbrushing was related to dental and oral hygiene status in a group of subjects that had never accessed dental and oral health services. In the group it was found that horizontal movement provides good dental and oral hygiene status and vertical movement gives poor dental and oral hygiene status. However, the cross-tabulation showed this to not be significant, so what is emphasized is the method of brushing that can clean the entire teeth to reduce the risk of plaque accumulation.

In this study the sub-variable of the duration of brushing teeth was observed through the video in getting the average subjects to brush their teeth for about 45.43 seconds. If the duration of brushing is associated with oral and oral hygiene status, in the group of subjects who brushed their teeth with a shorter duration had worse dental and oral hygiene status than the group of subjects who brushed their 
teeth longer. This is in accordance with the theory of Gans et al. (2009) that when brushing is performed for a short time, the results are not very good when compared with brushing teeth for longer, because it relates to the number of tooth surfaces to be cleaned (Gans et al., 2009). The result of cross-tabulation shows that the brushing duration has an odds ratio of 1.154 .

Based on the results of cross-tabulation, the duration of toothbrushing was associated with dental and oral hygiene status in the parent education group under senior high school, earning a high income, the group of subjects who had accessed dental and oral health services. In that group of subjects, it was found that good dental and oral hygiene status was associated with brushing teeth for a longer duration Although the duration did not reach the duration suggested by ADA it is good enough to describe the dental and oral hygiene status of the subject.

Based on the cross-tabulation of the dental and oral hygiene status of the subjects with the surface of the subject's toothbrush, the group of subjects whose surface bristles had been damaged had worse dental and oral hygiene status than the subjects whose toothbrush bristles were still good. The result of cross-tabulation had a p value equal to 0.036 so in this research there was a significant relation between dental and oral hygiene status with surface of the bristles of the toothbrush of subjects and an odds ratio of 3.120 which indicates that the group of subjects' toothbrush with a brittle surface had a 3 times higher risk of having a worse dental and oral hygiene status than that for which the surface of the toothbrush was still good. This is because a damaged toothbrush is not able to clean all parts of the teeth and oral cavity (Gans et al., 2009).

Based on the results of cross-tabulation it was found that toothbrush surface is related to the status of oral hygiene in the parent education group under senior high school, earning a high income, the subjects have no knowledge of how to maintain oral hygiene, and subjects who have never accessed dental and oral health services, where in this group if the surface of their toothbrush is in a good condition then their oral hygiene status is also good.

If the dental and oral hygiene status is crosstabulated with parental knowledge about the degree of stiffness of the subjects' toothbrush bristles, it was found that parents who have no knowledge of the degree of stiffness of toothbrush bristles have children with better dental and oral hygiene status. This is in fact contradictory to the theory that if parents have good knowledge about maintaining oral hygiene including knowing which toothbrush should be used, the dental and oral hygiene status will be better (Dharma, 2014). In older people who use soft toothbrushes, subjects had worse dental and oral hygiene status compared to subjects who used medium-hard toothbrushes. This is consistent with the theory that the effectiveness in removing plaque by each degree of toothbrush stiffness is different (Dharma, 2014). However, in children it is better to use a soft toothbrush, as using hard bristles can damage teeth and gums.

Generally a toothbrush needs to be replaced maximally every 3 months. In this study, not all parents had a period of toothbrush replacement, and only as many as 62 subjects had a replacement period. In parents who have a replacement period of more than 3 months, their child has a worse dental and oral hygiene status than parents who have a replacement period of less than 3 months. This is in accordance with the theory that an old toothbrush which is not replaced will make the process of cleaning the teeth and mouth not optimal, resulting in plaque accumulation (Muin, 2011).

Based on the results of cross-tabulation of the dental and oral hygiene status with the habit of brushing teeth, there are many results of crosstabulation analysis which show no significant result or $p$ value $>0.05$. Therefore, descriptive statistical analysis was conducted by using an odds ratio that is the size of exposure association of risk factors with the incidence of poor dental and oral hygiene status so that there are many risk factors that show a relation with dental and oral hygiene status. This condition shows the consequence of lacking large sample sizes of research due to technical constraints of data collection and the possibility of bias, especially information bias.

In the risk factor of habitual toothbrushing, not all factors can be cross-tabulated in certain groups. Only toothbrushing routine, toothbrushing, technique of toothbrushing, the period of toothbrushing and the shape of the toothbrush bristles if associated with behavioral theories will be associated with other risk factors such as parental background (education and parental income), toothache experience, experience of accessing dental and oral health services, and subjects' knowledge of how to maintain oral hygiene status.

Parents' background is related to dental and oral hygiene status in which the role of the parents is necessary in shaping the child's behavior in guiding, providing understanding, reminding and providing facilities to the child so that the child can maintain dental and oral hygiene (Mbawalla, Masalu, \& Astrom, 2010). If the subject has experience of 
toothache then it is possible to have access to dental and oral health services in the last 6 months. There is an opinion that the frequency of subjects accessing oral health services can improve oral hygiene, because there is education to maintain oral and dental hygiene from the dentist. Regarding the subject's knowledge, if subjects have poorly understood basic hygiene and oral hygiene, it will result in plaque accumulation to the severity of severe tooth and mouth disease due to the subject's ignorance of things that may harm the health of the teeth and oral cavity.

\section{ACKNOWLEDGEMENTS}

We gratefully thank SDN Pucang 3 Sidoarjo for allowing the authors to conduct a study there and also all the related parties for their valuable support and help during the study process.

\section{REFERENCES}

Bracika IG. 2014. Gambaran Perilaku Menggosok Gigi Pada Siswa SD Kelas Satu Dengan Karies Gigi Di Wilayah Kerja Puskesmas Rendang Karangasem Bali Oktober 2014. Mahasaraswati Dent J, Vol. 6 No. 1, pp.22-32.

Dharma MA. 2014. Pengaruh Kekakuan Bulu Sikat Gigi Terhadap Penurunan Jumlah Plak Pada Anak. Skripsi Sarjana, Universitas Mahasaraswati Denpasar: tidak diterbitkan.

Ganss C, Schlueter N, Preiss S, Klimek J. 2009. Tooth Brushing Habits In Uninstructed Adults Frequency, Technique, Duration And Force. Clin Oral Invest J, Vol. 13, pp.203-8.

Gopikrishna V, Bhaskar N, Kulkarni SB, Jacob J, Sourabha K. 2016. Knowledge, Attitude, And Practices Of Oral Hygiene Among College Students In
Bengaluru City. Indian Association of Public Health Dentistry J, Vol. 14 No. 1, pp.75

Hayasaki H, Saitoral hygiene I, Nakakura K, Hanasaki M, Nogami, Y, Nakajima T. 2014. Tooth brushing for oral prophylaxis. Japanese Dental Science Review, Vol. 50 No. 3, pp.69-77.

Maruanaya AM, Mariati NW, \& Pangemanan D. 2015. Gambaran Status Gingiva Menurut Kebiasaan Menyikat Gigi Sebelum Tidur Malam Hari Pada Siswa Sekolah Dasar Negeri 70 Manado. Je-GiGi (eG), Vol. 3 No. 2.

Mbawalla H, Masalu J, Astrom A. 2010. SocioDemographic And Behavioural Correlates Of Oral Hygiene Status And Oral Health Related Quality Of Life, The Limpopo - Arusha School Health Project (LASH): A Cross-Sectional Study. BMC Pediatrics $J$, Vol. 10 No. 87.

Muin M. 2011. Pengaruh Dental Health Education (DHE) Terhadap Penurunan Plak Gigi (Penelitian Dilakukan Pada Murid Sd Kelas IV Dan V Di Kelurahan Tamalanrea Indah Makassar). Skripsi Sarjana, Universitas Hasanuddin Makassar: tidak diterbitkan

Notoatmodjo, S. 2010. Ilmu Perilaku Kesehatan. Jakarta: Rineka Cipta.

Oberoi S, Moral hygieneanty V, Mahajan A, Oberoi A. 2014. Evaluating Awareness Regarding Oral Hygiene Practices And Exploring Gender Differences Among Patients Attending For Oral Prophylaxis. J Indian Soc Periodontal, Vol. 18 No. 3, pp.369-374.

Sabrina A, Subeqi T, Santoso D, Zulfa U, Atikah S, Felia M. 2015. Tingkat Keparahan Karies Gigi Siswa Sdn Warugumung I, Desa Warugunung, Kecamatan Pacet, Kabupaten Mojokerto, Jawa Timur Pada Bulan Mei 2015. Public Dental Health J.

Sasea A, Lampus BS, Supit A. 2013. Gambaran Status Kebersihan Rongga Mulut Dan Status Gingiva Pada Mahasiswa Dengan Gigi Berjejal. J e-gigi, Vol. 1 No.

Soesilo D, Santoso RE, Diyatri I. 2005. Peranan Sorbitol dalam Mempertahankan Kestabilan $\mathrm{pH}$ Saliva pada Proses Pencegahan Karies (The role of sorbitol in maintaining saliva's $\mathrm{pH}$ to prevent caries process). Dent. J, Vol. 38 No. 1, pp.25-8.

Trihono. 2013. Riset Kesehatan Dasar 2013 (RISKESDAS 2013). Laporan Nasional. P. 110-9 
Overview of the Oral Hygiene Status of Students in SDN Pucang 3 Sidoarjo Based on Their Toothbrushing Habit

\section{ORIGINALITY REPORT}

6

SIMILARITY INDEX
$2 \%$

INTERNET SOURCES

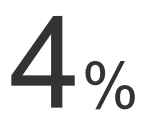

PUBLICATIONS
$0 \%$

STUDENT PAPERS

1 Richard F. Murphy. "AN ATTITUDE SCALE

FOR DENTAL HEALTH", Journal of School

Health, 05/1970

Publication

2 Siti Bahirrah. "Relationship of crowded teeth

and Oral Hygiene among urban population in

Medan", IOP Conference Series: Earth and

Environmental Science, 2018

Publication

3

Mohammad Abed Rabbo. "Dental care and treatment needs of elderly in nursing homes in

Saarland: perceptions of the homes managers :

Dental care and treatment needs of elderly in

nursing homes in Saarland", Gerodontology,

05/2011

Publication

4 pdgi.or.id

Internet Source

Hawa S Mbawalla. "Socio-demographic and 
behavioural correlates of oral hygiene status and oral health related quality of life, the Limpopo - Arusha school health project (LASH):

A cross-sectional study", BMC Pediatrics, 2010 Publication

6 Pallavi Petkar, Amith HV, Vinayak Kamath,

Bhanupriya Thakur. "Assessment of oral hygiene, periodontal status, dentition status and treatment needs among detainees in juvenile detention centres, of Madhya

Pradesh", Journal of Dental Health, Oral

Disorders \& Therapy, 2018

\section{Publication}

$7 \quad$ www.scitepress.org

Internet Source

8 docplayer.info

Internet Source

9 ir.uiowa.edu Internet Source

10 Masoomeh Shirzaiy, Galeh Mohageri.

"Evaluation DMFT and CPTIN Indices and

Related Personal Behaviors in the 12-Years-

Old Students", Dental Clinical and

Experimental Journal, 2018

Publication

Rita Rodrigues, Maria Helena Fernandes, 
António Bessa Monteiro, Rowney Furfuro et al. "Are there any solutions for improving the cleft area hygiene in patients with cleft lip and palate? A systematic review", International Journal of Dental Hygiene, 2019

Publication 


\section{Overview of the Oral Hygiene Status of Students in SDN Pucang 3 Sidoarjo Based on Their Toothbrushing Habit}

GRADEMARK REPORT

FINAL GRADE

10

PAGE 1

PAGE 2

PAGE 3

PAGE 4

PAGE 5

PAGE 6

PAGE 7

PAGE 8
GENERAL COMMENTS

Instructor 